\title{
Correction to: HIV infection and multidrug resistant tuberculosis: a systematic review and meta-analysis
}

Zeeba Zahra Sultana ${ }^{1}$, Farhana UI Hoque², Joseph Beyene ${ }^{3}$, Md. Akhlak-UI-Islam ${ }^{4}$ Md Hasinur Rahman Khan ${ }^{5}$, Shakil Ahmed ${ }^{6}$, Delwer Hossain Hawlader ${ }^{7}$ and Ahmed Hossain ${ }^{2,6,7^{*}}$

\section{Correction to: BMC Infect Dis 21, 51 (2021) https://doi.org/10.1186/s12879-020-05749-2}

After publication of the original article [1], the authors identified a typo in the Abstract, Methods section: it is written January 12,010, but it should be January 1, 2010.

The original article has been corrected.

\begin{abstract}
Author details
${ }^{1}$ CAPABLE- A Cambridge-led program in Bangladesh, University of Cambridge, Cambridge, UK. ${ }^{2}$ Department of Public Health, North South University, Dhaka, Bangladesh. ${ }^{3}$ Department of Health Research Methods, Evidence, and Impact, Faculty of Health Sciences, McMaster University, Hamilton, Ontario, Canada. ${ }^{4}$ Department of Hematology, Bangabandhu Sheikh Mujib Medical University, Dhaka, Bangladesh. Institute of Statistical Research and Training, University of Dhaka, Dhaka, Bangladesh. ${ }^{6} \mathrm{Global}$ Health Institute, North South University, Dhaka, Bangladesh. ${ }^{7}$ Health Management BD Foundation, Dhaka, Bangladesh.
\end{abstract}

Published online: 20 January 2021

\section{Reference}

1. Sultana, et al. HIV infection and multidrug resistant tuberculosis: a systematic review and meta-analysis. BMC Infect Dis. 2021;21:51 https://doi. org/10.1186/s12879-020-05749-2.

The original article can be found online at https://doi.org/10.1186/s12879020-05749-2

*Correspondence: ahmed.hossain@utoronto.ca

${ }^{2}$ Department of Public Health, North South University, Dhaka, Bangladesh

${ }^{6}$ Global Health Institute, North South University, Dhaka, Bangladesh

Full list of author information is available at the end of the article

(C) The Author(s). 2021 Open Access This article is licensed under a Creative Commons Attribution 4.0 International License, which permits use, sharing, adaptation, distribution and reproduction in any medium or format, as long as you give appropriate credit to the original author(s) and the source, provide a link to the Creative Commons licence, and indicate if changes were made. The images or other third party material in this article are included in the article's Creative Commons licence, unless indicated otherwise in a credit line to the material. If material is not included in the article's Creative Commons licence and your intended use is not permitted by statutory regulation or exceeds the permitted use, you will need to obtain permission directly from the copyright holder. To view a copy of this licence, visit http://creativecommons.org/licenses/by/4.0/ The Creative Commons Public Domain Dedication waiver (http://creativecommons.org/publicdomain/zero/1.0/) applies to the data made available in this article, unless otherwise stated in a credit line to the data. 